\title{
LITERASI MEDIA DIGITAL BAGI GURU PAUD GUGUS KENANGA DI KECAMATAN DUKUHSETI KABUPATEN PATI
}

\author{
Raodah dan Ali Subhan \\ Institut Pesantren Mathali'ul Falah, Indonesia \\ akfan_raodah@yahoo.com
}

\begin{abstract}
This outreach program is Digital Media Literacy Training for early childhood education (PAUD) Teachers of Kenanga Group in Dukuhseti district, Pati regency. This digital media literacy training activity aims to provide knowledge and insight into early childhood education (PAUD) Teachers to take advantage of digital-based media both in learning and administration. This outreach program was held for two days on Thursday-Friday, 29-30 August 2019 at TK Tunas Bangsa. The material presented includes; the urgency and function of digital media for learning and administration, typing using Microsoft Word, presenting with PowerPoint, scanning documents using a device, and using the WhatsApp application by computer or laptop. It is designed in the form of training using three methods. They are lecture method, demonstration method, and direct practice method. The results indicate that this program significantly increases in knowledge, understanding, expertise and, skills of the participants. It can be seen from the results of the pretest and posttest that have been implemented. Participants were also very satisfied with the dedication activities that had been carried out because the material presented was fit their needs and the methods used were also appropriate. From all the evaluation results in the form of pretest, posttest and feedback from the participants, it was concluded that this outreach program has achieved the goal they are the participants understand and can apply digital media for learning and administration.
\end{abstract}

Keywords: Literasi, Literasi media, Literasi Media Digital 


\section{Pendahuluan}

Revolusi industri memberikan dampak perubahan pada pola kehidupan manusia disegala lini. Revolusi industri ibarat dua mata uang yang memberikan dampak positif bila digunakan untuk hal-hal yang baik. Begitupun sebaliknya akan berdampak negatif jika tidak digunakan sebagaimana mestinya. Revolusi industri tidak dapat dibendung oleh siapapun.

Saat ini dunia berada pada revolusi industri 4.0 yaitu tren di dunia industri yang menggabungkan antara teknologi otomatisasi dengan tenaga siber. Hal ini ditunjukkan dengan digitalisasi diseluruh sektor kehidupan manusia. Manusia yang pada awalnya memegang peranan penting dalam kehidupan, sedikit demi sedikit bergeser digantikan oleh teknologi dan digital. Hal yang sangat menyita perhatian kita yaitu digerai-gerai tol yang awalnya dijalankan oleh manusia kini digantikan oleh sebuah mesin otomatis, dan masih banyak contoh lain dampak dari perkembangan teknologi digital menggilas peran vital manusia.

Digitalisasi adalah wujud dari perkembangan sebuah teknologi. Digitalisasi merupakan proses mengubah bentuk media yang awalnya berbentuk hard copy menjadi bentuk soft copy atau digital. Proses perubahan ini merupakan upaya untuk memberikan kemudahan kepada seseorang dalam mengakses informasi.

Vo1. 2 No. 1, April 2020

Raodah \& Ali Subhan| 2 gurnal Pengabdian Masyarakat 
Perkembangan media digital tidak hanya memberikan dampak pada sektor industri, namun segala sektor termasuk sektor pendidikan. Dahsyatnya pengaruh perkembangan teknologi dan media digital menyasar para kaula muda, orang tua bahkan anak kecil. Penggunaan kertas semakin berkurang, segala bentuk administrasi dan proses pembelajaran berbasis digital. Dengan mudahnya seseorang untuk mengakses informasi melalui internet, berkomunikasi dengan yang lainnya dengan telepon pintar, penyimpanan dokumen serta berbagi dokumen tanpa harus menggunakan alat tambahan berupa mesin scan, cukup dengan gawai segala urusan administrasi lebih mudah dan efisien.

Berdasarkan pengamatan di lapangan, bahwa Guru PAUD Gugus Kenanga tidak hanya berperan sebagai guru di lembaga pendidikan akan tetapi juga sebagai bagian dari administrasi lembaga pendidikan tersebut serta mereka mempunyai peran penting di masyarakat. Interaksi dengan media digital seperti komputer dan internet sudah menjadi bagian dari profesi mereka. Namun tidak sedikit dari anggota gugus kenanga yang berjumlah 40 orang telah melek teknologi, mereka menggunakan internet hanya untuk mengirim dan menerima pesan, mengecek media sosial, dan melihat gambar iklan komersial. Dalam hal ini, Guru PAUD Gugus Kenanga masih sebagai konsumen dari media 
digital yang mereka miliki tanpa mampu untuk mengubah peran media digital tersebut sebagai alat penunjang dari profesi mereka.

Melihat fenomena perkembangan teknologi dan media digital serta fakta yang terjadi di lapangan, perlu adanya literasi media digital kepada kepada masyarakat, khususnya Guru PAUD Gugus Kenanga Kecamatan Dukuhseti. Literasi media dapat diartikan sebagai suatu proses mengakses, menganalisis secara kritis pesan media, dan menciptakan pesan menggunakan alat media (Hobbs, 1996). Rubin (1998) menjelaskan bahwa yang dimaksud dengan literasi media adalah pemahaman sumber, teknologi komunikasi, kode yang digunakan, pesan yang dihasilkan, seleksi, interpretasi, dan dampak dari pesan tersebut.

Literasi digital disebut juga literasi komputer dan internet. Literasi media digital adalah sebuah konsep yang berkembang dan merupakan salah satu komponen dalam kemahiran literasi media yaitu kemahiran penggunaan komputer, internet, telepon, PDA dan peralatan digital yang lain. Dengan kata lain, literasi media digital adalah upaya yang dilakukan kepada masyarakat agar menjadi melek media digital sehingga mereka terlibat dalam penggunaan media digital tersebut, bukan sebagai konsumen namun sebagai produsen yang kritis dan kreatif. Literasi media digital harus dikembangkan dalam masyarakat 
kita karena tidak seorang pun manusia dilahirkan ke dunia ini dalam kondisi telah melek media, "No one is born media literate"1. (Encang Saepudin dkk: 2016)

Menurut Baran dan David (2010) ada lima hal yang mendasari pentingnya literasi media: Khalayak adalah aktif, tetapi belum sadar akan apa yang mereka lakukan dengan media. 2. Kebutuhan, kesempatan, dan pilihan khalayak didorong secara tidak alamiah oleh akses terhadap media dan konten media. 3. Konten media dapat secara implisit dan eksplisit memberikan tuntunan terhadap tindakan 4 . Orang-orang harus secara realistis mengukur bagaimana interaksi mereka dengan teks media dapat menentukan tujuan bahwa interaksi tersebut mendukung mereka di dalam lingkungan mereka. 5. Orang orang memiliki tingkatan berbeda dalam pengolahan kognitif, dan hal ini dapat secara radikal mempengaruhi bagaimana mereka menggunakan media dan apa yang bisa mereka dapatkan dari media.

Sedangkan menurut Brian Wright (2015) dalam Infographics yang berjudul Top 10 Benefits of Digital Literacy: Why You Should Care About Teknology: 1. It Save Time (Menghemat Waktu), 2. You Learn

${ }^{1}$ Encang Saepudin, dkk. "Literasi Media Bagi Guru PAUD Di Kecamatan Cicalengka". Dharmakarya, Vol.5, Nomor 1, diakses dari http://jurnal.unpad.ac.id/dharmakarya/article/view/9892. 2016. 
Faster (Belajar Lebih cepat), 3. You Save Money (Menghemat uang), 4. It Makes You Safer (Membuat Lebih Aman), 5. It Keeps You Informed (Selalu memperoleh informasi terkini), 6. It Keeps You Connected (Selalu Terhubung), 7. You'll Make Better Decisions (membuat keputusan yang lebih baik, 8. It Can Keep You Employed (dapat membuat anda bekerja), 9. It makes you happier (LOL) (membuat lebih bahagia), 10. You Can Influence The World.

Memberikan literasi media digital kepada Guru PAUD Gugus Kenanga Kecamatan Dukuhseti menjadi sangat penting dan sangat strategis. Karena mereka adalah pendidik anak usia dini dimana pondasi pendidikan dimulai pada tahap ini, mereka yang akan mentransfer nilai-nilai kebaikan dari teknologi dan digital kepada peserta didiknya. Disamping itu, peran mereka dalam sebuah instansi dan masyarakat sangat penting. Perlu diketahui zaman yang mereka lalui tidaklah semudah dan sesimple zaman sekarang. Untuk memberikan kemudahan dalam memperoleh dan mengolah serta memproduksi sebuah informasi, perlu kiranya diberikan sebuah pelatihan melek teknologi dan digital yaitu pelatihan literasi media digital melalui pelatihan Microsoft Word, penggunaan komputer untuk pembelajaran dengan menggunakan Microsoft Power Point, serta scan dokumen melalui telpon pintar tanpa harus menggunakan alat scan 
yang tidak dimiliki oleh semua orang serta menggunakan aplikasi Whatsapp melalui laptop agar lebih mudah mengirim dan menyimpan dokumen yang berkaitan dengan pembelajaran dan administrasi lembaga.

\section{Metode}

Kegiatan pengabdian kepada masyarakat ini dilakukan dengan menggunakan desain pelatihan. Karena salah satu karakteristik dan tahapan dalam pelatihan yaitu praktik dan simulasi. Hal ini sejalan dengan tujuan pengabdian kepada masyarakat yang diangkat yaitu memberikan literasi agar guru PAUD Gugus Kenanga Kecamatan Dukuhseti dapat mengaplikasikan media digital untuk menunjang profesinya. Kemampuan tersebut tidak dapat diserap jika hanya dengan penjelasan tanpa adanya simulasi. Maka dari itu, Pelatihan ini menggunakan beberapa metode yaitu: metode ceramah, demonstrasi, dan praktek langsung.

Metode ceramah merupakan metode yang hingga saat ini masih sering digunakan oleh instruktur atau guru yaitu suatu bentuk penyajian bahan pelajaran yang dilakukan oleh guru atau instruktur dengan penuturan atau penjelasan lisan secara langsung kepada siswa atau peserta. Penggunaan metode ini sangat menunjang dalam 
memberikan penjelasan tentang pentingnya literasi media digital terhadap guru PAUD Gugus Kenanga Kecamatan Dukuhseti agar mereka termotivasi untuk menerapkannya. Sedangkan metode demonstarsi merupakan metode yang sangat efektif untuk memperlihatkan atau mempertunjukkan kepada peserta tentang suatu proses (bekerjanya sesuatu, mengerjakan tindakan) dengan prosedur yang benar baik yang sebenarnya maupun sekedar tiruan. Metode ini dilakukan dalam menyajikan cara penggunaan Microsoft Word, membuat presentasi dengan powerpoint, menyambungkan Whatsapp ke laptop serta cara menggunakan scan via gawai atau telpon pintar sehingga materi dapat diserap dengan baik oleh peserta pelatihan. Disamping metode diatas, pelatihan literasi ini tidak lengkap tanpa adanya praktek langsung dari peserta pelatihan. Dalam pelatihan ini, peserta difasilitasi laptop untuk melakukan praktek langsung dari materi yang sudah disampaikan.

\section{Hasil Dan Pembahasan}

Era ini disebut dengan era digital, dimana digitalisasi merambah diseluruh bidang. Fenomena digitalisasi tidak dapat dibendung, mulai dari anak-anak hingga dewasa, petani hingga pejabat tinggi, siswa hingga guru. Alat digital dengan berbagai variasi dan fitur-fitur terbarukan selalu memberikan daya tarik kepada konsumennya dan 
memberikan kemudahan kepada penggunanya. Dampak dari penggunaan alat digital ibarat pisau yang dapat digunakan untuk hal positif juga dapat digunakan untuk hal negatif. Jadi, pengguna harus cerdas dalam penggunaan alat digital yang dimilikinya.

Penggunaan teknologi menjadi salah satu kompetensi yang harus dimiliki oleh guru saat ini. Administrasi surat-menyurat, pelaporan, serta materi pembelajaran di dalam kelas tidak lepas dari penggunaan komputer dan internet. Bahkan beberapa sekolah saat ini memberikan fasilitas komputer dan internet kepada guru untuk menunjang keberhasilan pendidikan. Hal ini menunjukkan bahwa pendidikan semakin baik dan mengikuti perkembangan zaman. Namun, tuntutan pendidikan dan perkembangan teknologi tidak selamanya sejalan dengan sumber daya manusia yang ada, dimana ketika ada salah satu guru yang sudah mampu untuk mengakses atau menggunakan alat digital, guru yang lain menganggap bahwa kewajiban mereka untuk menguasainya telah gugur, kemampuan komputer cukup dimiliki oleh kepala sekolah dan TU saja, alasan umur tidak lepas dari argumen mereka untuk menghindari penguasaan teknologi. Dapat dibayangkan seorang pendidik anak usia dini tidak cakap dalam menggunakan alat digital dalam pembelajaran sedangkan siswa meraka telah lihai dalam penggunaan alat digital. Berdasarkan fenomena diatas, menunjukkan 
bahwa kurangnya literasi penggunaan media digital kepada guru serta kegiatan literasi masih sangat minim diadakan untuk guru anak usia dini di Kecamatan Dukuhseti.

Salah satu kendala dalam penggunaan media digital untuk menunjang profesi Guru PAUD Gugus Kenanga Kecamatan Dukuhseti adalah kurangnya pemahaman dan penguasaan mereka dalam penggunaan media digital meskipun mereka telah memiliki medianya serta tidak adanya pelatihan untuk memfasilitasi mereka dalam penguasaan kompetensi tersebut. Padahal lembaga PAUD yang termasuk dalam gugus ini terbilang besar dan mewadahi satu Kecamatan Dukuhseti Kabupaten Pati yaitu 12 lembaga TK dan KB. Melihat kondisi diatas, perlu adanya upaya peningkatan pengetahuan, pemahaman, keterampilan dan keahlian para Guru PAUD Gugus Kenanga se Kecamatan Dukuhseti mengenai literasi penggunaan media digital untuk menunjang profesi mereka. Diharapkan dengan pelatihan ini akan memberikan dampak positif dan diperoleh hasil yang maksimal sehingga guru PAUD dapat menerapkannya dalam lingkungan lembaganya. Maka dari itu, pengabdian kepada masyarakat ini didesain dalam bentuk pelatihan bukan sosialisasi.

Pelaksanaan pengabdian kepada masyarakat ini melalui tiga tahapan yaitu tahapan persiapan, pelaksanaan dan evaluasi. Sebelum 
mencapai tiga tahapan diatas, terlebih dahulu diadakan observasi, wawancara dan FGD sebagai teknik dalam pengumpulan data awal pra pengabdian kepada masyarakat. Melalui teknik diatas kemudian diketahui permasalahan yang dihadapi oleh Guru PAUD Gugus Kenanga serta apa yang menjadi harapan mereka. Tahapan persiapan dalam pengabdian kepada masyarakat ini terdiri dari pembentukan tim pengabdian kepada masyarakat, mengidentifikasi dan menyusun usulan tema dan kegiatan pengabdian kepada masyarakat, merumuskan langkah-langkah kegiatan pengabdian kepada masyarakat, merumuskan materi pengabdian kepada masyarakat, mengumpulkan bahan materi pengabdian kepada masyarakat, menyusun materi pengabdian kepada masyarakat menjadi buku pedoman, menentukan metode pelaksanaan pengabdian kepada masyarakat. Tahapan pelaksanaan pengabdian kepada masyarakat ini terdiri dari menentukan khalayak sasaran pengabdian kepada masyarakat,menentukan jadwal dan waktu pelaksanaan kegiatan pengabdian kepada masyarakat, menyebarkan undangan pelaksanaan kegiatan pengabdian kepada masyarakat, pelaksanaan kegiatan pengabdian kepada masyarakat. Adapun tahapan laporan dan evaluasi terdiri dari pelaporan tertulis dan lisan. Laporan lisan berbentuk presentasi di depan reviewer sedangkan laporan tertulis berupa artikel 
jurnal pengabdian masyarakat.

Kegiatan pelatihan literasi media digital dilaksanakan dua hari yaitu pada hari kamis 29 Agustus 2019 dan hari jum'at 30 Agustus 2019 mulai pukul 09.00 - 12.00 di TK Tunas Bangsa Desa Kembang Kecamatan Dukuhseti Kabupaten Pati. Peserta yang hadir dalam pelatihan ini berjumlah 21 orang guru PAUD -sesuai dengan jumlah guru PAUD Gugus Kenanga yang kurang menguasai penggunaan alat digital- dengan usia yang bervariasi. Pelaksanaan pengabdian kepada masyarakat ini dengan menerapkan tiga metode yaitu; a. metode ceramah: untuk memberikan penjelasan pentingnya serta fungsi media digital bagi guru PAUD. b. metode demonstrasi yaitu metode yang digunakan untuk menjelaskan dan memvisualisasikan langkah-langkah penggunaan media digital untuk pembelajaran dan administrasi, untuk menunjang metode ini, tim pengabdian masyarakat menggunakan media proyektor dan membagikan buku panduan. c. Metode praktek langsung: pelatihan ini tidak cukup dengan penjelasan dan visualisasi langkah-langkah, maka peserta difasilitasi media digital berupa laptop dan telpon pintar agar peserta dapat melakukan praktek langsung sehingga mendapatkan pengalaman secara langsung.

Dalam pengabdian kepada masyarakat ini digunakan tiga pendekatan yaitu: a. Metode pengumpulan data awal: pelaksana 
kegiatan menghimpun data khalayak yang akan menjadi sasaran pelatihan dengan mewawancarai pihak guru PAUD TK Tunas Bangsa Kembang dan pengurus Gugus Kenanga Kecamatan Dukuhseti Kabupaten Pati kemudian melakukan FGD sehingga dapat diketahui point-point yang mejadi kebutuhan mereka. b. Metode pelaksanaan kegiatan: kegiatan dilaksanakan dengan desain pelatihan yang menggunakan teknik ceramah, tutorial, demonstrasi, dan praktek. c. Metode pengumpulan feed back yaitu dengan mengumpulkan kesan, saran dan kritik dari peserta setelah mengikuti kegiatan pelatihan ini.

Untuk mengetahui tingkat keberhasilan pengabdian kepada masyarakat ini, tim pelaksana menggunakan test berupa pretest dan posttest. Pretest dilaksanakan pada awal pelatihan. Tes ini dilakukan untuk mengetahui pemahaman awal peserta tentang tema yang akan dibahas, sedangkan posttest dilaksanakan diakhir pelaksanaan pelatihan. Hal ini dilakukan untuk mengukur ketercapaian tujuan pengabdian masyarakat ini. Selain itu, posttest dilakukan untuk mengetahui berapa persen dari peserta yang mampu memahami dan menyerap materi selama pelatihan berlangsung. Materi pretest dan posttest sama yaitu mengenai pemahaman peserta tentang literasi media digital dalam dunia pendidikan dan administrasi, peran dan pengaruh media digital terhadap guru PAUD, penggunaan media digital untuk 
pembelajaran dan administrasi, mengoperasionalkan komputer dengan baik, mengoperasionalkan Microsoft Word dan Power Point, penggunaan media digital gawai untuk administrasi.

Berdasarkan pelaksanaan pretest dan posttest diperoleh hasil yang sangat signifikan mengenai pemahaman dan kemampuan peserta dalam literasi media digital. Pre test dilaksanakan pada awal pelaksanaan pelatihan untuk mengetahui tingkat pemahaman peserta terhadap media digital dan penggunaannya sebelum diberikan pelatihan. Sedangkan posttest dilaksanakan setelah peserta menerima materi pelatihan tepatnya sebelum pelatihan berakhir. posttest ini bertujuan untuk mengukur tingkat ketercapaian tujuan pelatihan serta mengetahui seberapa besar keterserapan materi yang telah disampaikan.

Analisis terhadap hasil tes menunjukkan bahwa terdapat perubahan yang sangat besar mengenai pemahaman peserta dalam literasi media digital. Pengetahuan peserta tentang urgensi dan fungsi penggunaan media digital untuk pembelajaran dari hasil pre test diketahui 10 orang dari peserta mengetahui urgensi dan fungsinya atau 47,62\%, 11 dari peserta belum mengetahui urgensi dan fungsinya. . Sehingga belum ada satupun dari peserta pelatihan yang telah menggunakan media digital berupa laptop untuk pembelajaran. 
Kemudian pemahaman ini meningkat menjadi 100\% berdasarkan hasil post test. Sedangkan peserta yang mengetahui tentang penggunaan media digital gawai untuk urusan administrasi: $0 \%$ begitupun penggunaannya. Namun dari hasil post tes diketahui berbanding terbalik yaitu $100 \%$ dari peserta pelatihan mengetahui bahwa gawai dapat digunakan untuk urusan administrasi berupa scan dokumen dan lain-lain. Peserta yang mampu mengoperasionalkan komputer hanya 6 orang atau 28,57\%, yang dimaksud dengan mengoperasionalkan komputer disini adalah menyalakan komputer atau laptop serta menonaktifkannya dengan langkah yang benar. Setelah mengikuti pelatihan, 18 orang peserta atau 85,71\% mampu mengoperasionalkan komputer atau laptop tanpa bantuan tim pengabdian kepada masyarakat, sedangkan 3 orang peserta atau 14,29\% masih membutuhkan arahan dari tim pengabdian kepada masyarakat.

Dari hasil pre tes diketahui bahwa kemampuan peserta pelatihan dalam penulisan Microsoft Word meliputi; pengaturan font, ukuran, spasi, paragraf, penggunaan huruf kapital dan tata letak, hanya 2 orang peserta atau 9,52\%, sedangkan peserta yang memiliki kemampuan dalam penulisan presentasi menggunakan powerpoint, scan dokumen menggunakan media gawai serta menggunakan aplikasi Whatsapp untuk mengirim dan menerima dokumen melalui laptop adalah $0 \%$. 
Untuk empat tema ini, hasil post test yang menunjukkan kemampuan peserta digambarkan dalam bentuk penilaian dengan menggunakan huruf yaitu A = Istimewa, A- : Baik Sekali, B : Baik, B- : Cukup, C: Kurang. Penilaian ini kemudian dicantumkan dalam sertifikat yang diberikan kepada peserta. Peserta yang telah menguasai langkahlangkah penulisan di Microsoft Word, Nilai A: 85,71\%, Nilai A-: 14,29\%, Nilai B: 0\%. Peserta yang telah mampu membuat presentasi dengan menggunakan power point, Nilai A: 71,43\%, Nilai A-: 19,05 \%, Nilai B: 9,5\%. Semua peserta setelah mendapatkan pelatihan mengunduh aplikasi scanner di hp yaitu aplikasi Camsanner. Adapun peserta yang mendapatkan nilai maksimal dalam mengaplikasikan aplikasi ini adalah 71,43\% dengan nilai A, 19,05 \% dengan nilai A-, dan 9,5\% mendapatkan nilai B. Adapun kemampuan dalam menggunakan aplikasi Whatsapp di laptop untuk mengirim pesan dan dokumen serta menyimpannya, peserta yang memperoleh Nilai A: 71,43\%, Nilai A-: 19,05 \%, Nilai B: $9,5 \%$.

Selain pretest dan posttest, untuk mengukur keberhasilan program pengabdian masyarakat ini, penyelenggara melakukan evaluasi kegiatan secara keseluruhan dengan cara meminta feed back kepada peserta berupa pertanyaan terbuka tentang kesan mereka terhadap isi materi yang disampaikan, metode yang digunakan, media 
yang digunakan, waktu pelatihan, penyampaian materi oleh tutor, sarana dan prasarana. Berdasarkan hasil feed back tersebut diketahui bahwa materi yang disampaikan sesuai dengan kebutuhan peserta di lapangan. Mereka mendapatkan banyak ilmu dan keterampilan baru terutama penggunaan gawai untuk urusan administrasi. Karena hal ini belum mereka ketahui sebelumnya.

\section{Simpulan}

Secara umum, pelaksanaan pengabdian kepada masyarakat berupa pelatihan literasi media digital bagi guru PAUD Gugus Kenanga Kecamatan Dukuhseti Kabupaten Pati dapat memberikan dan meningkatkan pengetahuan, pemahaman, pengalaman serta keahlian para guru dalam menggunakan media digital untuk pembelajaran dan administrasi.

Dari hasil pretest dan posttest diketahui bahwa perubahan pengetahuan dan keahlian serta keterampilan guru dalam menggunakan media digital terdapat perubahan yang sangat signifikan. Hal ini dikarenakan sebelumnya mereka belum mendapatkan literasi dalam bentuk pelatihan atau sejenisnya. Sehinggan pelatihan ini memberikan manfaat secara teoritis kepada guru PAUD gugus Kenanga berupa dapat menambah khazanah keilmuan mereka dalam mengkaji lebih jauh tentang penggunaan media digital untuk pembelajaran dan 
administrasi. Sedangkan manfaat praktis yang telah mereka peroleh berupa peningkatan dalam kompetensi penggunaan teknologi khususnya media digital dalam pembelajaran dan administrasi.

\section{Daftar Pustaka}

Abidin, Yunus. Mulyati, Tita. Yunansah, Hana. Pembelajaran Literasi Strategi Meningkatkan Kemampuan Literasi Matematika, Sains, Membaca, dan Menulis. Jakarta: Bumi Aksara, 2017.

Fathurrohman, Pupuh dan Sutikno, M Sobry. Strategi Belajar Mengajar: Strategi Mewujudkan Pembelajaran Bermakna Melalui Pemahaman Konsep Umum dan Islami. Bandung: Refika Aditama. 2014.

Ferrington, G. What is media literacy? Diakses dari http://interact.uoregon.edu/mediaLit/mlr/readings/article s/whatisml.html. 2006.

E-book. Maulana, Murad. Definisi, Manfaat dan Elemen Penting Literasi Digital.

Mufarokah, Annisatul. Strategi Belajar Mengajar. Yogyakarta: Teras, 2009.

Potter, J.W. Media Literacy, New York: Sage, 2013.

Rachmi Adiarsi, Gracia, dkk. Literasi Media Internet di Kalangan 
Mahasiswa, Humaniora Vol 6, No. 4 Oktober 2015.

Rusman. Kurniawan, Deni. Riyana, Cecep. 2013. Pembelajaran Berbasis

Teknologi Informasi dan Komunikasi Mengembangkan

Profesionalitas Guru. Jakarta: Rajagrafindo Persada.

Saepudin, Encang. Agustini Damayani, Ninis. Sukaesih. 2016. “Literasi

Media Bagi Guru PAUD Di Kecamatan Cicalengka".

Dharmakarya, Vol. 5, Nomor 1, diakses dari http://jurnal.unpad.ac.id/dharmakarya/article/view/9892.

Tambaruka, Apriadi. Literasi Media: Cerdas Bermedia Khalayak Media Massa. Jakarta: Rajawali Pers, 2013. 


\section{JURNAL}

\section{As-Sidanah}

\section{Vol. 02 No. 1, April 2020}

